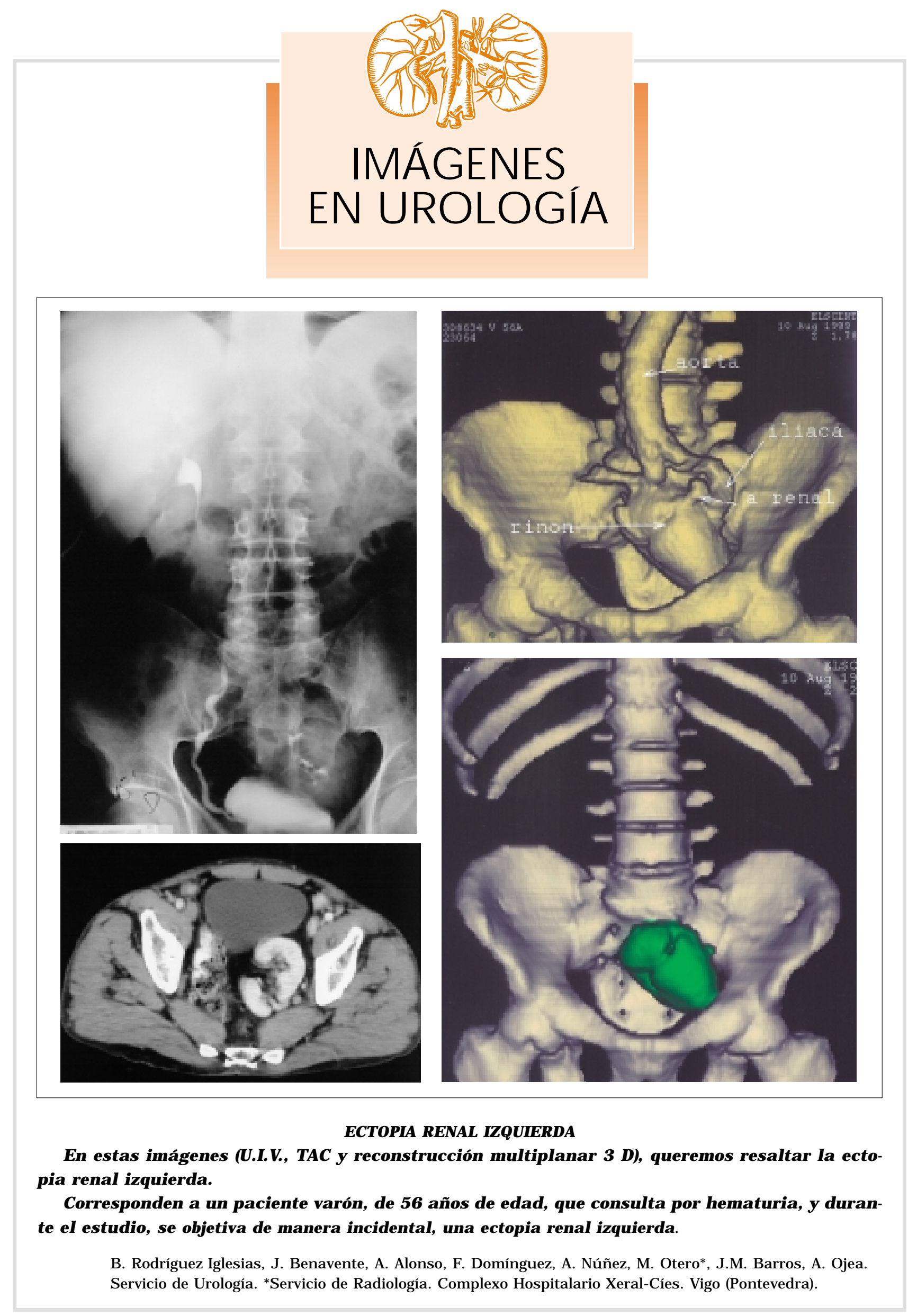



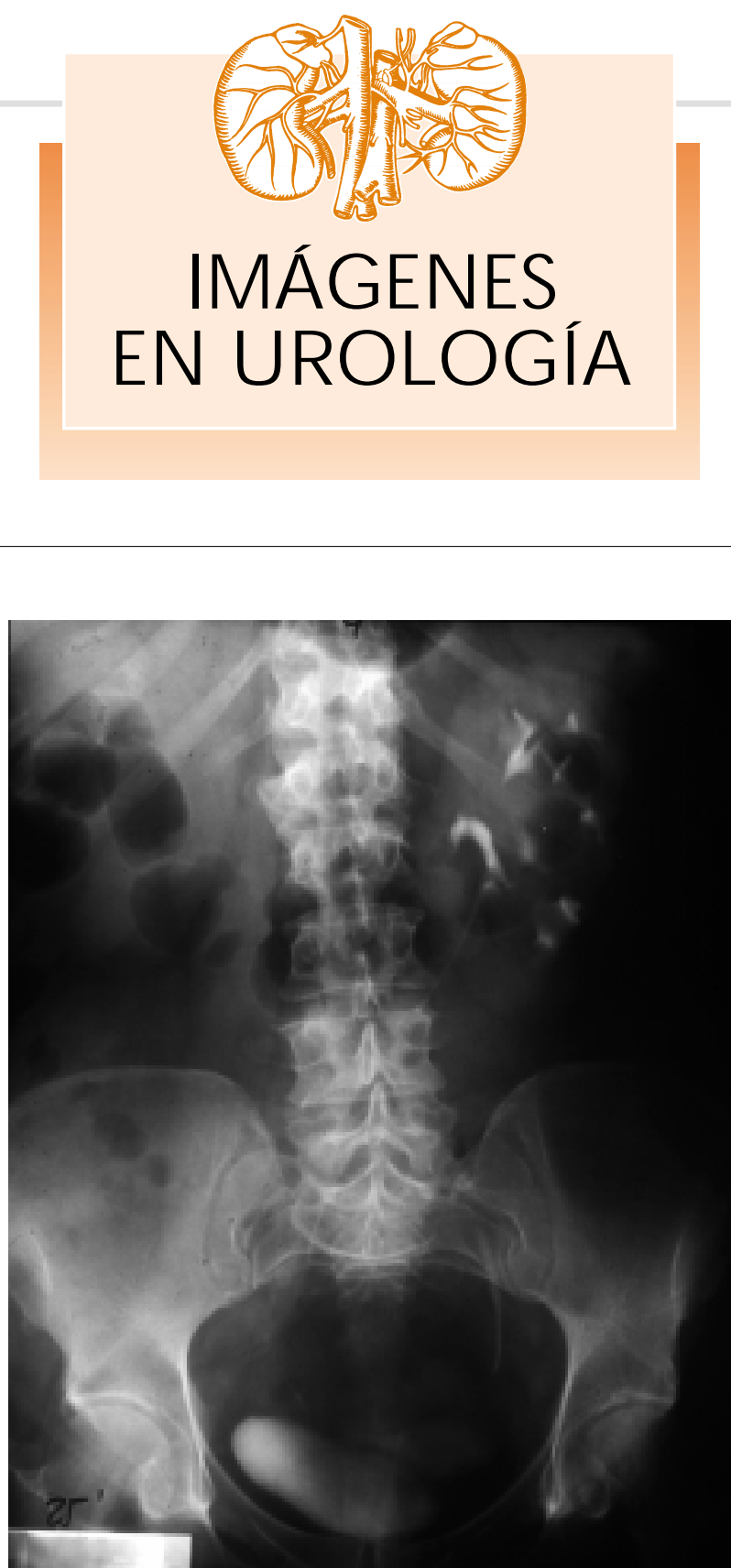

\section{ECTOPIA RENAL CRUZADA}

Paciente mujer de 58 años, que consulta en el servicio de digestivo por dispepsia. Dentro de las pruebas solicitadas por dicho servicio se incluye un estudio ecográfico. En dicho estudio se informa la ausencia de riñón derecho describiéndose como agenesia renal y riñón izquierdo compensador.

Para completar estudios solicitamos urografia intravenosa (Figura), en la que en lugar de riñón compensador se evidencia una ectopia renal cruzada fusionada.

La paciente está asintomática desde el punto de vista urológico, no precisando ningún tipo de actitud terapéutica.

O. Rodríguez Faba, A. San Martín Blanco, J.M. Fernández Gómez, J. García Rodríguez, A. Jalón Monzón, J.J. Rodríguez Martínez, F. Martínez Gómez, J. Regadera Sejas, J.L. Martín Benito, A. Sánchez Trilla Servicio de Urología I. Hospital Central de Asturias. Asturias. 